\title{
Effect of Surface Coatings and Packaging Materials on Quality of Apple Ber (Zizyphus mauritiana) at Different Storage Conditions
}

\author{
H. Bhavana ${ }^{1}$, Veena Joshi ${ }^{2 *}$, M. Sreedhar ${ }^{3}$ and R. Purnima Mishra ${ }^{4}$ \\ ${ }^{1}$ College of Horticulture-Rajendranagar, ${ }^{2}$ Horticulture, College of Horticulture- \\ Rajendranagar, Sri Konda Laxman Telangana State Horticultural University (SKLTSHU), \\ Rajendranagar, Telangana, India \\ ${ }^{3}$ Genetics \& Plant Breeding, MFPI-Quality Control Laboratory, Professor Jayashankar \\ Telangana State Agricultural University, Rajendranagar, India \\ ${ }^{4}$ Agricultural Engineering, College of Horticulture-Rajendranagar, Sri Konda Laxman \\ Telangana State Horticultural University (SKLTSHU), Rajendranagar, India \\ *Corresponding author
}

\section{A B S T R A C T}

\section{Keywords}

Apple ber, Surface coatings, Packaging materials, Storage conditions, Quality, chitosan, Aloe vera, room temperature, Cold storage, High density polyethylene, Polypropylene

\section{Article Info}

Accepted:

15 December 2018

Available Online:

10 January 2019
Apple ber (Zizyphus mauritiana) is a Thailand variety ber belongs to the family Rhamnaceae. Apple ber is developed by grafting Thailand green apple with Thai local ber. In the studies conducted on effect of surface coatings and packaging materials on quality of Apple ber (Zizyphus mauritiana) at different storage conditions at College of Horticulture- Rajendranagar, SKLTSHU, Rajendranagar. The experiment was conducted in two factor completely randomized design with three replications in which factor one includes nine treatments of surface coatings and packaging materials along with control (without any surface coating and packaging). Factor two includes two storage condition $\mathrm{S}_{1}$-cold storage $\left(10 \pm 2^{\circ} \mathrm{C}\right)$ and $\mathrm{S}_{2}$-room temperature $\left(22 \pm 2^{\circ} \mathrm{C}\right)$ and observations were recorded at 3 days interval upto end of shelf life of fruits. Results indicated that surface coatings, packaging materials and different storage conditions affected the quality of apple ber. Maximum TSS $\left(15.96^{\circ}\right)$ and titrabale acidity $(0.15)$ was recorded by $\mathrm{P}_{5} \mathrm{~S}_{1}$, at the end of shelf life and according to organoleptic evaluation $\mathrm{P}_{4} \mathrm{~S}_{1}$ recorded the high score. Among interaction effects Chitosan $1 \%+$ HDPE (High Density Polyethylene) + cold storage $\left(10 \pm 2^{\circ} \mathrm{C}\right)$ is best of all the treatments followed by Chitosan $1 \%+\mathrm{PP}$ (Polypropylene) + cold storage.

\section{Introduction}

Apple ber (Zizyphus mauritiana) is a hardy minor tropical fruit, belongs to the family Rhamnaceae. This fruit resembles green apple in its appearance and tastes like ber, hence the name Apple ber. It is also called as Apple plum or Jujube berry. It is also popularly known as "Telangana Apple" in Telangana state. The genus Ziziphus comprises about 40 species distributed throughout the tropical and subtropical regions of the world. Among various species, mauritiana is commercially cultivated for its nutritive and edible fruits. It 
is popularly known as poor man's fruit of tropics.

In India apple ber cultivation first started in Maharashtra, later extended to other states like Gujarat and Telangana. In Telangana it is cultivated commercially in Hyderabad, Mahbubnagar, Medak, Warangal and Khammam districts. It is also popularly known as "Telangana Apple" in Telangana state. The heaviness of each fruit is $60-150 \mathrm{~g}$. It is very attractive, sweet, crispy and juicy. In current years farmers are showing interest in cultivation of apple ber when compared to ber due to its unique traits like thorn less nature, high yielding, early crop, ease of cultivation in terms of harvesting and wider adaptability to grow in any type of soil with less consumption of water. It has ability to withstand extreme summer, heavy rains, heavy winds and extreme winter. It starts yielding in nine months. Fruits are produced mainly from November to March with nominal first crop of $20-25 \mathrm{~kg}$ per tree and second crop will be around $50 \mathrm{~kg}$ per tree and third year onwards yield will be $100 \mathrm{~kg}$ to 200 $\mathrm{kg}$ per tree.

The edible or surface coatings are defined as thin layer of material that covers the surface of the fruit and can be eaten as part of the whole product. Surface coatings when applied to fruits help in extending their shelf life by acting as a barrier between atmosphere and fruit surface. Among this most commonly and widely used surface coatings are aloe vera and Chitosan. (Milena et al., 2014)

Aloe vera is a well-known plant for its marvelous medicinal properties. It prolongs the conservation of fresh fruits. This natural product is a safe and environmentally friendly. Aloe vera gel forms a protective layer against the oxygen and moisture of the air and inhibits the action of micro-organisms that causes food borne illnesses through its various antibacterial and antifungal compounds, it also prevents loss of moisture, retains firmness, controls respiratory rate and maturation (Jawadul et al., 2014).

Chitosan is a natural polymer obtained by deacetylation of chitin shells of shrimp and other crustaceans. Chitosan has several advantages such as bio-compatibility, biodegradability and no toxicity over other polysaccharides. Although this surface coating has many advantages in preservation of postharvest fruits and vegetables, simple coating sometimes limits inhibition to microorganism that leads fruits to decay due to lack of permeability of carbon dioxide and oxygen. To effectively apply the surface coatings, it should be combined with other substances through physical methods viz. short heating (or) short gas fumigation (or) packaging (Padmaja and Bosco, 2014; Milena et al., 2014; Adetunji et al., 2014; Duan and Zhang, 2013).

Packing fresh fruits and vegetables is one of the most important steps in the long and complicated journey from grower to consumer. A package provides protection, tampers resistance and improves the shelf life and quality of fruits. Generally ber fruits are packed in CFB (Corrugated fiber board) boxes or HDPE (High density polyethylene) or in PP (Polypropylene) which reduces moisture loss from fruits during storage (Sharma et al., 2013; Manpreet et al., 2009). Since past two years, Apple ber fruits are rushing into markets resulting in glut, hence there is a need for proper packaging and storage of fruits for further supply (Lal et al., 2002).

\section{Materials and Methods}

The experiment was conducted at College of Horticulture, Sri Konda Laxman Telangana State Horticultural University, Rajendranagar, 
Hyderabad and MFPI-Quality Control Laboratory, PJTSAU, Rajendrana during the year 2016-2017. Apple ber fruits used for research were procured from the orchard in Medak district, Hyderabad.

The experiment was conducted in two factor completely randomized design with three replications. Factor one includes nine treatments $\mathrm{P}_{1}-$ Aloe vera gel $(1: 3)+\mathrm{HDPE}$ (High Density Polyethylene), $\mathrm{P}_{2}-$ Aloe vera gel (1:3) + PP (Polypropylene), $\mathrm{P}_{3}-$ Aloe vera gel $(1: 3)+\mathrm{CFB}$ (Corrugated Fiberboard), $\mathrm{P}_{4}-$ Chitosan 1\% + HDPE (High Density Polyethylene), $\mathrm{P}_{5}-$ Chitosan $1 \%+$ PP (Polypropylene), $\mathrm{P}_{6}-$ Chitosan $1 \%+\mathrm{CFB}$ (Corrugated Fiberboard), $\mathrm{P}_{7}-$ Aloe vera gel (1:3), $\mathrm{P}_{8}-$ Chitosan $1 \%, \mathrm{P}_{9}-$ Control(without any surface coating and packaging)and factor two includes two storage condition $\mathrm{S}_{1}$-cold storage $\left(10 \pm 2^{\circ} \mathrm{C}\right)$ and $\mathrm{S}_{2}$-room temperature $\left(22 \pm 2^{\circ} \mathrm{C}\right)$.

\section{Materials and Methods}

\section{Preparation of treatment solutions}

\section{Preparation of aloe vera gel}

Fresh aloe Vera leaves collected from Medicinal and Aromatic Plants Research Station were washed to remove the dust, aloe vera gel matrix was separated from the outer cortex of leaves using knife and then the colorless hydro parenchyma was grinded in a blender and strained through muslin cloth to remove thick particles. Take $1 \%$ of pectin with amount of water which is going to mix with aloe vera gel and heat to the required temperature. Mix both water and aloe vera gel in the ratio of 1:3 for treatment of fruits.

\section{Preparation of chitosan solution}

$1 \%$ chitosan solution was prepared by dissolving $10 \mathrm{~g}$ of chitosan powder in $1000 \mathrm{ml}$ of distilled water. Mature green stage fruits of apple ber were selected and the fruits were washed thoroughly under running tap water to remove the adherent dirt material.

Fruits were treated with 1:3 aloe vera gel for 10 minutes and then allowed to air dry for 2030 minutes in shade, similarly fruits were dipped in $1 \%$ chitosan solution for 10 minutes and air dried before packing in 100 gauge High Density Polyethylene (HDPE), Polypropylene (PP) bags and CFB (Corrugated Fiberboard) boxes.

10 fruits were packed for each treatment and kept in both ambient conditions in a room at $22 \pm 2^{\circ} \mathrm{C}$ and in cool chamber $\left(10 \pm 1^{\circ} \mathrm{C}\right)$ according to treatments. The analysis of the fruits was done after removal from the package at every 3 days intervals for Total soluble sugars, titable acidity, brix acid ratio, ascorbic acid content, total sugars, reducing sugars, non-reducing sugars and organoleptic evaluation.

\section{Total soluble solids (TSS)}

The total soluble solids were determined by using ERMA hand refractometer and expressed as ${ }^{\circ}$ Brix (Ranganna, 1986).

\section{Titrable acidity (\%)}

Ten grams of sample was taken, ground well and transferred to volumetric flask and volume was made up to $100 \mathrm{ml}$ with distilled water.

The contents were filtered through Whatmann No.1 filter paper. An aliquot of $10 \mathrm{ml}$ was taken into conical flask to which 2-3 drops of phenolphthalein indicator was added and titrated against $0.1 \mathrm{~N} \mathrm{NaOH}$ till a pink colour was obtained which persists at least for 15 seconds, as an end point (Ranganna, 1986). 
Acidity $=$

Titre value x Normality of $\mathrm{NaOH}$ x 0.0064 x 100

Volume of aliquot taken

\section{Brix: acid ratio}

Brix acid ratio was calculated by dividing the T.S.S value with the acid value (Titratable Acidity).

\section{Organoleptic evaluation}

\section{Organoleptic characters}

The organoleptic characters viz., colour and appearance, texture, taste, flavor and overall acceptability of apple ber fruits at the end of their shelf life were evaluated on five point hedonic scale using the score card mentioned below (Ranganna, 1986).

$\begin{array}{lc}\text { Hedonic scale } & \text { Scores } \\ \text { Highly acceptable } & 5 \\ \text { Acceptable } & 4 \\ \text { Fairly acceptable } & 3 \\ \text { Poorly acceptable } & 2 \\ \text { Not acceptable } & 1\end{array}$

\section{Results and Discussion}

\section{Total soluble solids ( ${ }^{\circ}$ Brix $)$}

The synergistic effect of surface coatings and packaging at different storage conditions of apple ber on total soluble solids is presented in the Table 1.

Total soluble solids increases with the storage period in room temperature- $S_{2}$ up to $9^{\text {th }}$ day and it start decreasing from $12^{\text {th }}$ day. In $\mathrm{S}_{2^{-}}$ cold storage TSS increased till $18^{\text {th }}$ day of storage later it shown decreasing trend. Rapid increase in TSS indicates that the fruit is ripening at a faster rate compared to other fruits. Among the storage conditions significantly highest TSS (13.21), (14.56) was recorded by $\mathrm{S}_{2}$-room temperature and lowest TSS was recorded by $S_{1}$-cold storage (12.75), (13.93) and on $6^{\text {th }}$ and $9^{\text {th }}$ day respectively. On $12^{\text {th }}$ day and $15^{\text {th }}$ day $S_{1}$ recorded highest TSS (14.71), (15.25) and $S_{2}$ recorded lowest TSS (13.02), (12.93) respectively.

Among interactions $\mathrm{P}_{5} \mathrm{~S}_{1}$-chitosan $(1 \%)+\mathrm{PP}$ packing + cold storage recorded highest TSS of (15.34) and (16.76) on $12^{\text {th }}$ and $15^{\text {th }}$ day respectively.

Total soluble solids increased in all the fruits as the fruit converts their complex carbohydrates to simple sugars during ripening Padmaja and Bosco (2014). $\mathrm{P}_{5} \mathrm{~S}_{1^{-}}$ chitosan $(1 \%)+$ PP packing + cold storage was best treatment with maximum TSS. Baviskar et al., (1995) also reported that TSS of ber fruits increases to peak and declined gradually during storage.

\section{Titrable acidity (\%)}

Results on titrable acidity of apple ber stored at both cold storage and room temperature affected by surface coatings and packaging material was presented in the Table 2. Acidity of a fruits decreases with the progress in the storage period.

There was no significant difference among treatments in different storage conditions on $3^{\text {rd }}$ and $6^{\text {th }}$ day and on $9^{\text {th }}$ day there was no significant difference among interactions and among two factors. With respect to storage conditions minimum acidity was recorded by $\mathrm{S}_{1}$-cold storage (0.46), (0.42), (0.32) and $(0.28)$ on $3^{\text {rd }}, 6^{\text {th }}, 12^{\text {th }}$ and $15^{\text {th }}$ days respectively and $\mathrm{S}_{2^{-}}$room temperature recorded maximum acidity (0.48), (0.43), $(0.33)$ and $(0.28)$ on $3^{\text {rd }}, 6^{\text {th }}, 12^{\text {th }}$ and $15^{\text {th }}$ days respectively. 
Table.1 Effect of surface coatings and packaging materials at different storage conditions on total soluble solids ( $\left.{ }^{\circ} \mathrm{B}\right)$ of Apple ber (Zizyphus mauritiana)

\begin{tabular}{|c|c|c|c|c|c|c|c|c|c|c|c|c|c|c|c|c|c|c|c|}
\hline \multicolumn{20}{|c|}{ TSS $\left({ }^{\circ} \mathbf{B}\right)$} \\
\hline & \multicolumn{3}{|c|}{$3^{\text {rd }}$ Day } & \multicolumn{3}{|c|}{$6^{\text {th }}$ Day } & \multicolumn{3}{|c|}{$9^{\text {th }}$ Day } & \multicolumn{3}{|c|}{$12^{\text {th }}$ Day } & \multicolumn{3}{|c|}{$15^{\text {th }}$ Day } & \multicolumn{2}{|c|}{$18^{\text {th }}$ Day } & \multicolumn{2}{|c|}{$21^{\text {st }}$ Day } \\
\hline & $\mathbf{S}_{1}$ & $\mathbf{S}_{2}$ & Mean & $\mathbf{S}_{1}$ & $\mathbf{S}_{2}$ & Mean & $\mathbf{S}_{1}$ & $\mathbf{S}_{2}$ & Mean & $\mathbf{S}_{1}$ & $\mathbf{S}_{2}$ & Mean & $\mathbf{S}_{1}$ & $\mathbf{S}_{2}$ & Mean & $\mathbf{S}_{1}$ & $\mathbf{S}_{2}$ & $\mathbf{S}_{1}$ & $\mathbf{S}_{2}$ \\
\hline $\mathbf{P}_{1}$ & 11.06 & 12.36 & 11.71 & 12.16 & 13.36 & 12.76 & 13.83 & 14.23 & 14.03 & 15.94 & 13.05 & 14.49 & 16.13 & 12.83 & 14.48 & 16.30 & $*$ & 15.61 & $*$ \\
\hline $\mathbf{P}_{2}$ & 11.76 & 12.13 & 11.94 & 12.33 & 12.73 & 12.53 & 13.36 & 14.36 & 13.86 & 14.52 & 13.16 & 13.84 & 14.68 & 12.53 & 13.60 & 15.96 & $*$ & 14.43 & $*$ \\
\hline $\mathbf{P}_{3}$ & 12.06 & 11.06 & 11.56 & 12.56 & 12.36 & 12.46 & 13.86 & 14.86 & 14.36 & 13.93 & 12.43 & 13.18 & 14.06 & $*$ & - & 15.86 & $*$ & $*$ & $*$ \\
\hline $\mathbf{P}_{4}$ & 11.16 & 11.90 & 11.53 & 12.18 & 12.20 & 12.19 & 13.16 & 13.40 & 13.28 & 15.21 & 13.36 & 14.28 & 16.30 & 13.13 & 14.71 & 16.86 & $*$ & 15.73 & $*$ \\
\hline $\mathbf{P}_{5}$ & 11.10 & 11.50 & 11.30 & 12.26 & 12.40 & 12.33 & 13.12 & 13.70 & 13.41 & 15.34 & 13.50 & 14.42 & 16.76 & 13.26 & 15.01 & 16.92 & $*$ & 15.96 & $*$ \\
\hline $\mathbf{P}_{6}$ & 11.66 & 11.76 & 11.71 & 13.40 & 12.00 & 12.70 & 13.53 & 14.80 & 14.16 & 14.30 & 12.63 & 13.46 & 14.63 & $*$ & - & 14.93 & $*$ & $*$ & $*$ \\
\hline $\mathbf{P}_{7}$ & 12.53 & 11.73 & 12.13 & 13.10 & 14.76 & 13.93 & 14.80 & 15.50 & 15.15 & 14.36 & $*$ & - & 15.10 & * & - & 15.63 & $*$ & $*$ & $*$ \\
\hline $\mathbf{P}_{8}$ & 12.60 & 12.50 & 12.55 & 13.73 & 14.20 & 13.96 & 14.86 & 15.66 & 15.26 & 14.23 & $*$ & - & 15.40 & $*$ & - & 15.60 & $*$ & * & $*$ \\
\hline $\mathbf{P}_{9}$ & 12.90 & 12.63 & 12.76 & 13.06 & 14.90 & 13.98 & 14.92 & * & - & 14.56 & $*$ & - & 14.23 & $*$ & - & 15.80 & $*$ & $*$ & $*$ \\
\hline Mean & 11.87 & 11.95 & & 12.75 & 13.21 & & 13.93 & 14.56 & & 14.71 & 13.02 & & 15.25 & 12.93 & & 15.98 & - & 15.43 & - \\
\hline & & ${ }^{\mathrm{d} d}$ Day & & $6^{\text {th }}$ & Day & & $9^{\text {th }} D$ & & & $2^{\text {th }}$ Day & & 15 & Day & & $18^{\text {th }} \mathrm{D}$ & & & $1^{\text {st }}$ Day & \\
\hline & S.Em \pm & & & S.Em \pm & CD at $5 \%$ & S.E & & CD at $5 \%$ & S.Em \pm & CD & at $5 \%$ & S.Em \pm & $\begin{array}{c}\text { CD at } \\
5 \%\end{array}$ & S. & $\mathbf{E m} \pm$ & $\begin{array}{c}\text { CD at } \\
5 \%\end{array}$ & S.Em \pm & & $\begin{array}{l}\text { CD at } \\
5 \%\end{array}$ \\
\hline$P$ & 0.18 & & IS & 0.69 & NS & 0. & & NS & 0.68 & & 1.96 & 0.10 & 0.31 & & 0.08 & 0.23 & 0.05 & & 0.16 \\
\hline$S$ & 0.08 & & IS & 0.32 & 0.93 & 0 . & & 0.21 & 0.32 & & .92 & 0.05 & 0.14 & & 0.38 & 0.11 & 0.02 & & 0.07 \\
\hline$P X S$ & 0.26 & & IS & 0.98 & NS & 0. & & NS & 0.97 & & 2.78 & 0.15 & 0.44 & & 0.11 & 0.33 & 0.07 & & 0.22 \\
\hline
\end{tabular}

* - end of shelf life. TSS of apple ber on $0^{\text {th }}$ day $-10.21^{\circ} \mathrm{B}$.

$\mathrm{P} 1$ - Aloe vera gel+HDPE, $\mathrm{P} 2-$ Aloe veragel+PP, $\mathrm{P} 3-$ Aloe veragel+CFB, $\mathrm{P} 4-$ Chitosan+HDPE, $\mathrm{P} 5-\mathrm{Chitosan}+\mathrm{PP}, \mathrm{P} 6-\mathrm{Chitosan}+\mathrm{CFB}, \mathrm{P} 7-$ Aloe vera gel,

P8 - Chitosan, P9 - Control,

$\mathrm{S} 1$ - cold storage, S2 - room temperature. 
Table.2 Effect of surface coatings and packaging materials at different storage conditions on titrable acidity (\%) of Apple ber (Zizyphus mauritiana)

\begin{tabular}{|c|c|c|c|c|c|c|c|c|c|c|c|c|c|c|c|c|c|c|c|}
\hline \multicolumn{20}{|c|}{ Titrable acidity $(\%)$} \\
\hline & \multicolumn{3}{|c|}{$3^{\text {rd }}$ Day } & \multicolumn{3}{|c|}{$6^{\text {th }}$ Day } & \multicolumn{3}{|c|}{$9^{\text {th }}$ Day } & \multicolumn{3}{|c|}{$12^{\text {th }}$ Day } & \multicolumn{3}{|c|}{$15^{\text {th }}$ Day } & \multicolumn{2}{|c|}{$18^{\text {th }}$ Day } & \multicolumn{2}{|c|}{$21^{\text {st }}$ Day } \\
\hline & $\mathbf{S}_{1}$ & $\mathbf{S}_{2}$ & Mean & $\mathbf{S}_{1}$ & $\mathbf{S}_{2}$ & Mean & $\mathbf{S}_{1}$ & $\mathbf{S}_{2}$ & Mean & $\mathbf{S}_{1}$ & $\mathbf{S}_{2}$ & Mean & $\mathbf{S}_{1}$ & $\mathbf{S}_{2}$ & Mean & $\mathbf{S}_{1}$ & $\mathbf{S}_{2}$ & $\mathbf{S}_{1}$ & $\mathbf{S}_{2}$ \\
\hline $\mathbf{P}_{1}$ & 0.46 & 0.48 & 0.48 & 0.40 & 0.43 & 0.41 & 0.36 & 0.36 & 0.36 & 0.32 & 0.33 & 0.32 & 0.28 & 0.29 & 0.28 & 0.22 & $*$ & 0.15 & $*$ \\
\hline $\mathbf{P}_{2}$ & 0.45 & 0.48 & 0.48 & 0.42 & 0.43 & 0.42 & 0.36 & 0.38 & 0.37 & 0.31 & 0.34 & 0.32 & 0.27 & 0.30 & 0.28 & 0.24 & $*$ & 0.16 & $*$ \\
\hline $\mathbf{P}_{3}$ & 0.49 & 0.50 & 0.50 & 0.42 & 0.45 & 0.43 & 0.36 & 0.38 & 0.37 & 0.32 & 0.35 & 0.33 & 0.28 & $*$ & - & 0.25 & $*$ & $*$ & $*$ \\
\hline $\mathbf{P}_{4}$ & 0.46 & 0.45 & 0.45 & 0.40 & 0.40 & 0.40 & 0.35 & 0.36 & 0.35 & 0.30 & 0.31 & 0.30 & 0.26 & 0.27 & 0.26 & 0.20 & $*$ & 0.14 & $*$ \\
\hline $\mathbf{P}_{5}$ & 0.45 & 0.49 & 0.49 & 0.41 & 0.46 & 0.43 & 0.35 & 0.35 & 0.35 & 0.31 & 0.31 & 0.31 & 0.26 & 0.28 & 0.27 & 0.21 & * & 0.15 & $*$ \\
\hline $\mathbf{P}_{6}$ & 0.45 & 0.52 & 0.52 & 0.41 & 0.41 & 0.41 & 0.35 & 0.37 & 0.36 & 0.33 & 0.34 & 0.33 & 0.29 & $*$ & - & 0.25 & * & $*$ & $*$ \\
\hline $\mathbf{P}_{7}$ & 0.48 & 0.5 & 0.50 & 0.42 & 0.44 & 0.43 & 0.38 & 0.39 & 0.38 & 0.35 & $*$ & - & 0.30 & $*$ & - & 0.26 & * & $*$ & $*$ \\
\hline $\mathbf{P}_{8}$ & 0.45 & 0.47 & 0.4 & 0.45 & 0.45 & 0.45 & 0.36 & 0.38 & 0.37 & 0.36 & $*$ & - & 0.30 & $*$ & - & 0.25 & * & $*$ & $*$ \\
\hline $\mathbf{P}_{9}$ & 0.50 & 0.51 & 0.5 & 0.45 & 0.46 & 0.45 & 0.37 & $*$ & - & 0.36 & $*$ & - & 0.31 & $*$ & - & 0.27 & * & * & $*$ \\
\hline Mean & 0.46 & 0.48 & & 0.42 & 0.43 & & 0.36 & 0.37 & & 0.32 & 0.33 & & 0.28 & 0.285 & & 0.23 & - & 0.15 & - \\
\hline & $3^{\text {rd }}$ & Day & & $6^{\text {th }}$ & & & $9^{\text {th }} D$ & & & ${ }^{\text {th }}$ Day & & $15^{\text {th }}$ & Day & & $18^{\text {th }}$ & Day & & $1^{\text {st }}$ Day & \\
\hline & S.Em \pm & $\begin{array}{c}\text { CD } \\
5\end{array}$ & & S.Em \pm & $\begin{array}{c}\text { CD at } \\
5 \%\end{array}$ & S.E & & $\begin{array}{c}\text { CD at } \\
5 \%\end{array}$ & S.Em \pm & & & S.Em \pm & $\begin{array}{c}\text { CD at } \\
5 \%\end{array}$ & S.E & $m \pm$ & $\begin{array}{c}\text { CD at } \\
5 \%\end{array}$ & S.Em \pm & & \\
\hline$P$ & 0.020 & $\mathrm{~N}$ & & 0.037 & NS & 0.0 & & NS & 0.006 & 0.1 & 018 & 0.004 & 0.012 & 0.1 & 005 & 0.015 & 0.009 & & 018 \\
\hline$S$ & 0.009 & 0.0 & & 0.017 & 0.051 & 0.0 & & NS & 0.003 & 0. & 009 & 0.006 & NS & 0.1 & 007 & 0.020 & 0.004 & & 010 \\
\hline$P X S$ & 0.028 & $\mathrm{~N}$ & & 0.053 & NS & 0.0 & & NS & 0.009 & 0. & 027 & 0.010 & 0.031 & 0. & 012 & 0.035 & 0.013 & & 028 \\
\hline
\end{tabular}


Table.3 Effect of surface coatings and packaging materials at different storage conditions on brix acid ratio of Apple ber (Zizyphus mauritiana)

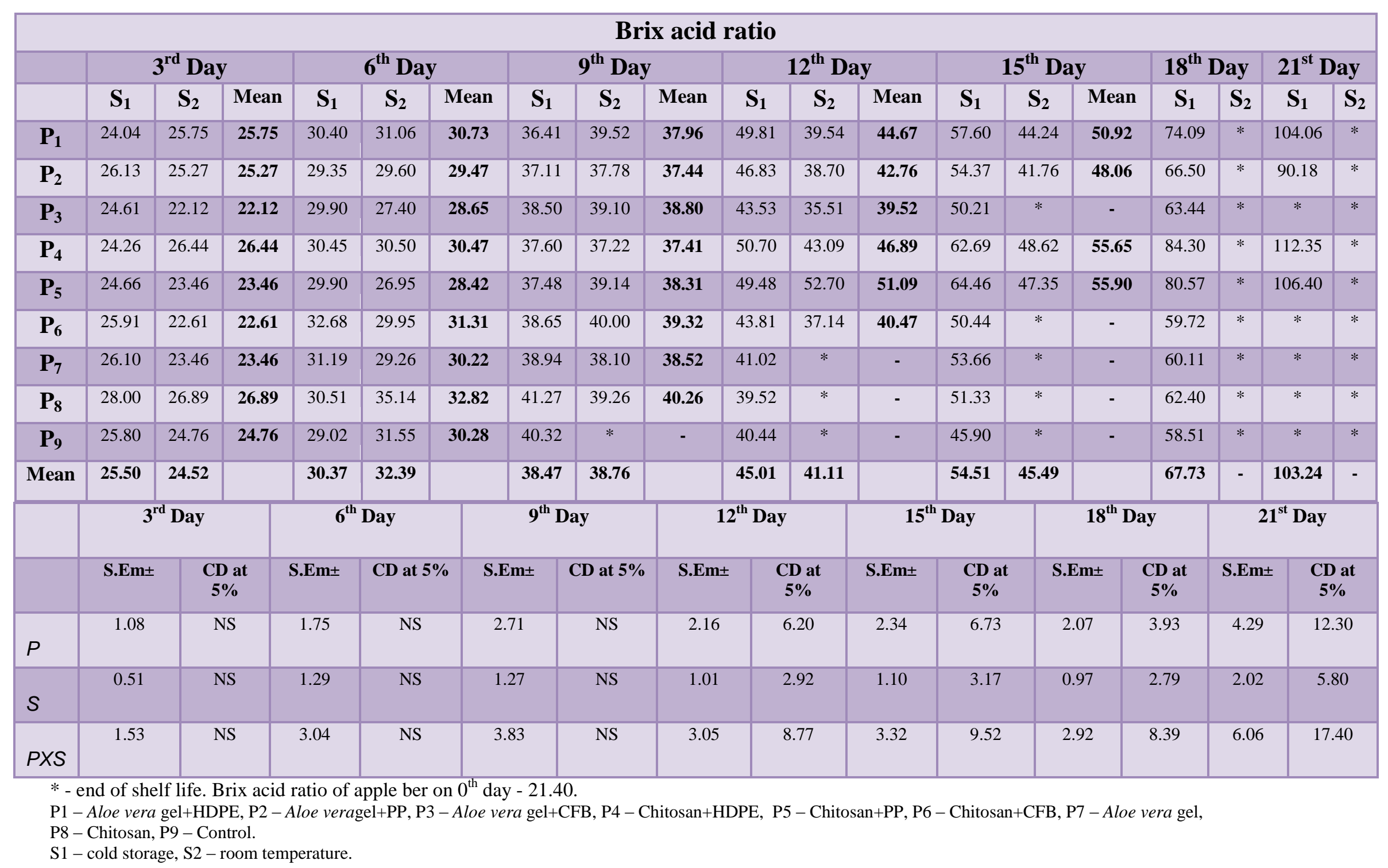


Table.4 Effect of surface coatings and packaging materials at different storage conditions on organoleptic evaluation of Apple ber (Zizyphus mauritiana)

\begin{tabular}{|c|c|c|c|c|c|c|c|c|c|c|c|c|c|c|c|}
\hline \multicolumn{16}{|c|}{ Organoleptic evaluation } \\
\hline & \multicolumn{3}{|c|}{$\begin{array}{l}\text { Colour and } \\
\text { appearance }\end{array}$} & \multicolumn{3}{|c|}{ Texture } & \multicolumn{3}{|c|}{ Taste } & \multicolumn{3}{|c|}{ Flavour } & \multicolumn{3}{|c|}{ Overall acceptability } \\
\hline & $\mathbf{S}_{1}$ & $\mathbf{S}_{\mathbf{2}}$ & Mean & $\mathbf{S}_{1}$ & $\mathbf{S}_{\mathbf{2}}$ & Mean & $\mathbf{S}_{1}$ & $\mathbf{S}_{\mathbf{2}}$ & Mean & $\mathbf{S}_{1}$ & $\mathbf{S}_{2}$ & Mean & $\mathbf{S}_{1}$ & $\mathbf{S}_{\mathbf{2}}$ & Mean \\
\hline $\mathbf{P}_{1}$ & 3.12 & 2.81 & 2.96 & 4.16 & 4.03 & 4.09 & 4.25 & 4.00 & 4.12 & 4.32 & 4.23 & 4.27 & 4.01 & 3.97 & 3.99 \\
\hline $\mathbf{P}_{2}$ & 3.28 & 2.85 & 3.06 & 4.09 & 4.00 & 4.04 & 3.80 & 3.90 & 3.85 & 3.78 & 3.67 & 3.72 & 3.63 & 4.00 & 3.81 \\
\hline $\mathbf{P}_{5}$ & 3.46 & 3.01 & 3.23 & 4.27 & 4.11 & 4.19 & 4.23 & 4.20 & 4.21 & 4.48 & 4.22 & 4.35 & 4.20 & 4.00 & 4.10 \\
\hline $\mathbf{P}_{6}$ & 2.86 & 2.64 & 2.75 & 3.96 & 3.80 & 3.88 & 3.80 & 3.70 & 3.75 & 3.78 & 3.74 & 3.76 & 3.82 & 3.46 & 3.64 \\
\hline $\mathbf{P}_{7}$ & 2.32 & 2.19 & 2.25 & 3.60 & 3.43 & 3.51 & 3.59 & 3.89 & 3.74 & 4.00 & $3.8 \mathrm{C}$ & 3.94 & 3.56 & 3.33 & 3.44 \\
\hline $\mathbf{P}_{8}$ & 2.56 & 2.16 & 2.36 & 3.23 & 2.96 & 3.09 & 3.66 & 3.75 & 3.70 & 3.64 & 3.75 & 3.69 & 3.49 & 3.16 & 3.32 \\
\hline & S.En & & CD at $5 \%$ & S.Em \pm & & CD at $5 \%$ & S.Em \pm & & D at $5 \%$ & S.Em & & CD at $5 \%$ & S.En & & D at $5 \%$ \\
\hline$P$ & 0.0 & & 0.11 & 0.05 & & 0.16 & 0.04 & & 0.12 & 0.08 & & 0.23 & $0.0^{\circ}$ & & 0.22 \\
\hline$S$ & 0.0 & & 0.05 & 0.02 & & 0.07 & 0.02 & & 0.06 & 0.0 & & 0.09 & 0.0 & & 0.10 \\
\hline$P X S$ & 0.0 & & 0.16 & 0.08 & & 0.23 & 0.06 & & 0.18 & 0.1 & & 0.32 & 0.10 & & 0.31 \\
\hline
\end{tabular}

$\mathrm{P} 1$ - Aloe vera gel+HDPE, P2 - Aloe vera gel+PP, P3 - Aloe veragel+CFB, P4 - Chitosan+HDPE, P5 - Chitosan+PP, P6 - Chitosan+CFB, P7 - Aloe vera gel, P8 - Chitosan, P9 - Control,

S1 - cold storage, S2 - room temperature. 
Fig.1 Effect of surface coatings and packaging materials at different storage conditions organoleptic evaluation of Apple ber (Zizyphus mauritiana)

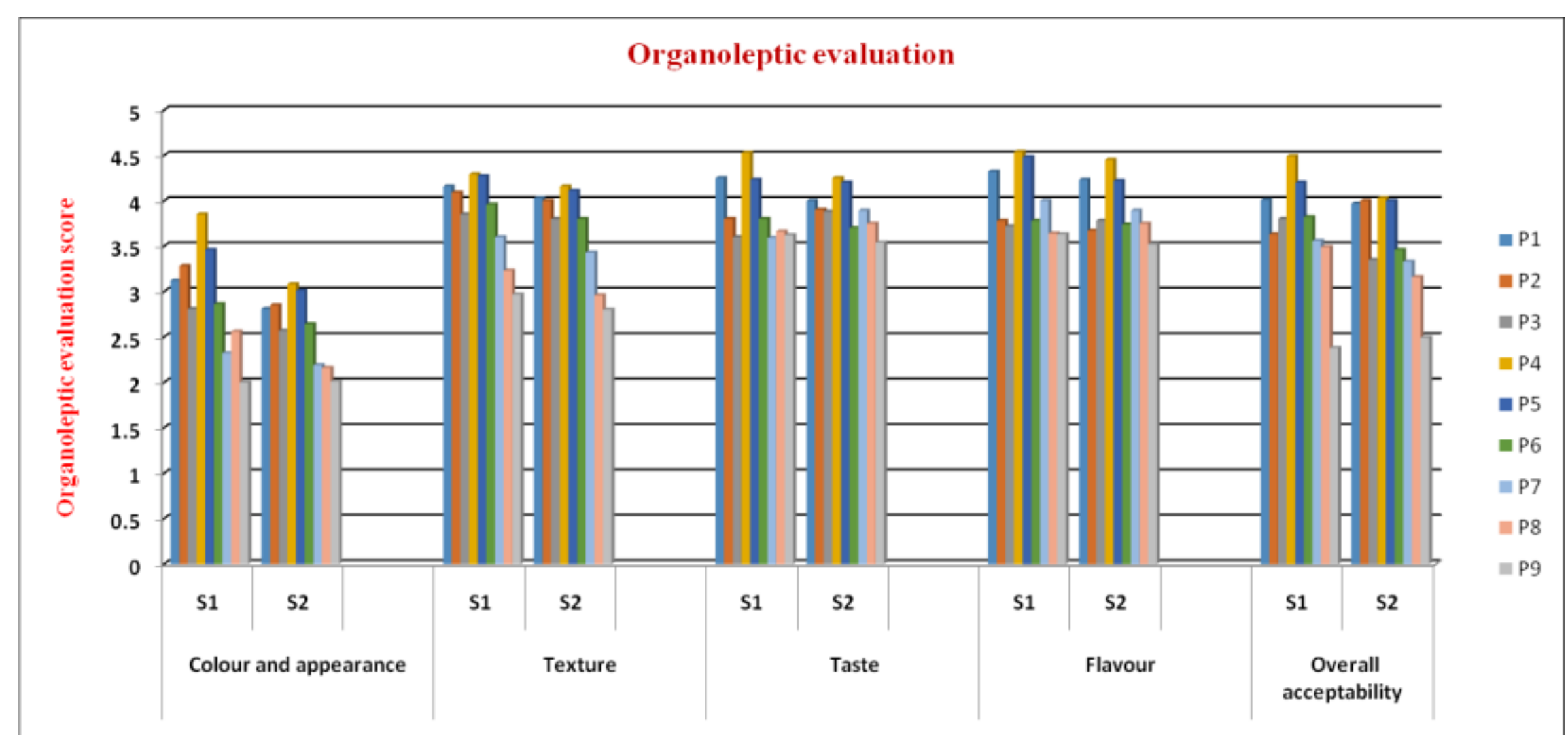


Titrable acidity of fruits decreases due to increase of soluble sugars during course of ripening. This decrease was observed less in fruits coated with surface coating compared to control due to edible coatings, packaging and low temperature. $\mathrm{P}_{4} \mathrm{~S}_{1}$-chitosan $(1 \%)+\mathrm{HDPE}$ + cold storage is the best treatment with least acidity, similar findings were reported by Bavikar et al., (1995) in ber fruits were acidity decreased continuously towards the end of storage period regardless of postharvest treatments and storage conditions.

\section{Brix acid ratio}

Effect of surface coatings, packaging materials and different storage conditions on apple ber is presented in the Table 3 . It is the ratio of TSS and acidity which increased with the storage period.

There was no significant difference among the treatments, storage conditions and also in interaction of treatments and storage conditions on $3^{\text {rd }} \cdot 6^{\text {th }}$ and $9^{\text {th }}$ day.

Brix acid ratio on $21^{\text {st }}$ day was highest in $\mathrm{P}_{4} \mathrm{~S}_{1}$ - chitosan $(1 \%)+$ HDPE + cold storage (112.35) and highest was in $\mathrm{P}_{2} \mathrm{~S}_{1^{-}}$aloe vera gel (1:3) + PP + cold storage (90.18).

With respect to interactions highest brix acid ratio was recorded by $\mathrm{P}_{4} \mathrm{~S}_{1}-$ chitosan $(1 \%)+$ HDPE + cold storage $(50.70)$ on $12^{\text {th }}$ day and $\mathrm{P}_{5} \mathrm{~S}_{1}$ - chitosan $(1 \%)+\mathrm{PP}+$ cold storage (64.46) on $15^{\text {th }}$ day.

Among the storage conditions highest brix acid ratio (45.01) and (54.51) was recorded in $\mathrm{S}_{1}$-cold storage and lowest (41.11) and (45.49) was recorded in $S_{2}$-room temperature on $12^{\text {th }}$ and $15^{\text {th }}$ day respectively.

Brix acid ratio increases as TSS increases in storage period. This increase was constant initially, but later it showed decreasing trend. Treated fruits showed slow rate of decrease over control fruits.

\section{Organoleptic evaluation}

Results of organoleptic evaluation of apple ber (Zizyphus mauritiana) including colour and appearance, texture, taste, flavour and overall acceptability are presented in the Table 4 and Figure 1.

Organoleptic evaluation was done by a panel of 5 judges at the end of shelf life of the treatments and scores were given according to scale 1-5. Scores for colour and appearance, texture, taste and flavour were given by sensory evaluation whereas over acceptability scores were given by considering all the characters like colour, taste, flavor, texture, aroma etc.

$\mathrm{P}_{4}$-chitosan $(1 \%)+\mathrm{HDPE}$ treated fruits recorded highest score for colour and appearance of fruits (3.46) and lowest was in $\mathrm{P}_{9}$-control (2.00).

There was a significant difference among all interactions. Score of colour was recorded highest in $\mathrm{P}_{4} \mathrm{~S}_{1}-$ chitosan $(1 \%)+\mathrm{HDPE}+$ cold storage (3.85).

Score of texture was recorded highest in $\mathrm{P}_{4-}$ chitosan (1\%) + HDPE (4.19) and $\mathrm{P}_{1}$ (4.09) and lowest score was recorded by $\mathrm{P}_{9}$-control (2.88). Among interactions highest score for texture was recorded by $\mathrm{P}_{4} \mathrm{~S}_{1}-$ chitosan $(1 \%)$ + HDPE + cold storage (4.29).

For taste highest score was recorded in $\mathrm{P}_{5}-$ chitosan (1\%) + PP (4.39) and lowest score was recorded by $\mathrm{P}_{9}$-control (3.58). $\mathrm{P}_{5} \mathrm{~S}_{1-}$ chitosan $(1 \%)+\mathrm{PP}+$ cold storage recorded highest score (4.53).

Score of flavour was recorded highest in $\mathrm{P}_{4}-$ chitosan (1\%) + HDPE (4.49) and lowest score was recorded by $\mathrm{P}_{9}-$ control (3.57). $\mathrm{P}_{4} \mathrm{~S}_{1}$ - chitosan $(1 \%)+$ HDPE + cold storage 
recorded highest score (4.54) in flavor among interactions.

Highest score for overall acceptability was recorded in $\mathrm{P}_{4}$ - chitosan (1\%) + HDPE (4.26) and lowest score was recorded by $\mathrm{P}_{9}-$ control (2.43). Among interactions highest score in overall acceptability was recorded in $\mathrm{P}_{4} \mathrm{~S}_{1}$ Chitosan $(1 \%)+$ HDPE + cold storage (4.49) which was the best treatment according to organoleptic evaluation, this treatment was in marketable condition even after 21 days followed by $\mathrm{P}_{5} \mathrm{~S}_{1}$ - Chitosan $(1 \%)+\mathrm{PP}+$ cold storage.

It can be concluded that total soluble solids (TSS) increases as the storage period increases and decreases when fruit starts deteriorating, but in case on titrable acidity it decreases as the storage period increases. According to brix acid ratio and organoleptic evaluation $\mathrm{P}_{4} \mathrm{~S}_{1}$ - Chitosan $1 \%+\mathrm{HDPE}$ (High Density Polyethylene) + cold storage was best of all the treatments with a shelf life of 21 followed by $\mathrm{P}_{5} \mathrm{~S}_{1^{-}}$Chitosan $1 \%+\mathrm{PP}$ (Polypropylene) + cold storage with shelf life of 20.33 days.

\section{References}

Adetunji, C. O. Fadiji, A. E and Aboyeji, O. 2014. Effect of chitosan Coating Combined Aloe Vera Gel on Cucumber (Cucumis sativa L.) Post-Harvest Quality during Ambient Storage. Journal of Emerging Trends in Engineering and Applied Sciences. 5(6): 391-397.

Baviskar, M. R. Waskar, D. P and Kaulgud, S. N. 1995. Effect of various post-harvest treatments on shelf life and quality of ber fruits. Indian Journal of Horticulture. 52(1): 37-45.

Duan, J and Zhang, S. 2013. Application of Chitosan Based Coating in Fruit and Vegetable Preservation: A Review. Journal of Food Processing And Technology. 4(5): 2157-7110.

Jawadul, M. Fatema, H. B and Hoque, M. M. 2014. Aloe veragel as a Novel Edible Coating for Fresh Fruits:A Review. American Journal of Food Science and Technology. 2(3):93-97.

Lal, G. Fageria, M. S. Narendra, K. G. Dhaka, R. S and Khandelwal, S. K. 2002. Shelf-life and quality of ber (Ziziphusmauritiana Lamk) fruits after postharvest water dipping treatments and storage. The Journal of Horticultural Science and Biotechnology. 77:576- 579.

Manpreet, K. Ashok, K and Mahesh, K. 2009. Storage studies of Ber in polymeric films. Journal of Agricultural Engineering. 46(4): 141-144.

Milena, P. Francesco, M. Maria, S. P. Luigi, Z. Elvira, N. Giuseppe, C and Marco, S. 2014. Effect of Chitosan Coating on the Postharvest Quality and Antioxidant Enzyme System Response of Strawberry Fruit during Cold Storage. Foods. 4:501523.

Padmaja, N and Bosco, S. J. 2014. Preservation of Jujube fruits by edible aleo vera gel coating to maintain quality and safety. Indian Journal of Science Research and Technology. 2(3): 79- 88.

Sharma, S. R. Surekha, B. Sadhna, A. Mittal, T. C and Gupta, S. K. 2013. Effect of storage conditions and packaging material on quality of anardana. International Journal of Advances in Engineering and Technology. 6(5): 2179-2186.

\section{How to cite this article:}

Bhavana, H., Veena Joshi, M. Sreedhar and Purnima Mishra, R. 2019. Effect of Surface Coatings and Packaging Materials on Quality of Apple Ber (Zizyphus mauritiana) at Different Storage Conditions. Int.J.Curr.Microbiol.App.Sci. 8(01): 2326-2336.

doi: https://doi.org/10.20546/ijcmas.2019.801.244 